\title{
Gender Specific Influence of Fish Oil or Atorvastatin on Functional Properties of Renal Na,K-ATPase in Healthy Wistar and Hypertriglyceridemic Rats
}

\author{
N. VRBJAR ${ }^{1}$, L. MÉZEŠOVÁ ${ }^{1}$, V. JAVORKOVÁ ${ }^{1}$, J. VLKOVIČOVÁ ${ }^{1}$, M. MITAŠÍKOVÁ ${ }^{1}$, \\ K. DLUGOŠOVÁ ${ }^{1}$, L. OKRUHLICOVÁ ${ }^{1}$, N. TRIBULOVÁ ${ }^{1}$
}

${ }^{1}$ Institute for Heart Research, Department of Biochemistry, Slovak Academy of Sciences, Bratislava, Slovak Republic

Received January 26, 2011

Accepted July 29, 2011

On-line October 12, 2011

\begin{abstract}
Summary
For better understanding of pathophysiological processes leading to increased retention of sodium as a consequence of hyperlipidemia, the properties of renal $\mathrm{Na}$, K-ATPase, a key enzyme involved in maintaining sodium homeostasis in the organism, were studied. Enzyme kinetics of renal Na,K-ATPase were used for characterization of ATP- and $\mathrm{Na}^{+}$-binding sites after administration of fish oil (FO) (30 mg.day $\left.{ }^{-1}\right)$ or atorvastatin $\left(0.5 \mathrm{mg} \cdot 100 \mathrm{~g}^{-1}\right.$. day $\left.{ }^{-1}\right)$ to healthy Wistar rats and rats with hereditary hypertriglyceridemia of both genders. Untreated healthy Wistar and also hypertriglyceridemic female rats revealed higher $\mathrm{Na}$, K-ATPase activity as compared to respective untreated male groups. Hypertriglyceridemia itself was accompanied with higher $\mathrm{Na}, \mathrm{K}$ ATPase activity in both genders. Fish oil improved the enzyme affinity to ATP and $\mathrm{Na}^{+}$, as indicated by lowered values of $\mathrm{K}_{\mathrm{m}}$ and $\mathrm{K}_{\mathrm{Na}}$ in Wistar female rats. In Wistar male rats FO deteriorated the enzyme in the vicinity of the $\mathrm{Na}^{+}$-binding site as revealed from the increased $K_{\mathrm{Na}}$ value. In hypertriglyceridemic rats $\mathrm{FO}$ induced a significant effect only in females in the vicinity of the sodium binding sites resulting in improved affinity as documented by the lower value of $\mathrm{K}_{\mathrm{Na}}$. Atorvastatin aggravated the properties of $\mathrm{Na}, \mathrm{K}$ ATPase in both genders of Wistar rats. In hypertriglyceridemic rats protection of $\mathrm{Na}$, K-ATPase was observed, but this effect was bound to females only. Both treatments protected renal $\mathrm{Na}$, K-ATPase in a gender specific mode, resulting probably in improved extrusion of excessive intracellular sodium out of the cell affecting thus the retention of sodium in hHTG females only.
\end{abstract}

\section{Key words}

Sodium pump • Kidney • Hereditary hypertriglyceridemia • Sex difference

\section{Corresponding author}

N. Vrbjar, Institute for Heart Research, Department of Biochemistry, Slovak Academy of Sciences, Dúbravská cesta 9, 840 05 Bratislava 45, P.O.Box 104, Slovak Republic. Fax: 0042125477 6637. E-mail: usrdnorb@savba.sk

\section{Introduction}

Hypertriglyceridemia, independently of cholesterol level, is associated with an increased risk of cardiovascular diseases and it may be followed by development of atherosclerosis and hypertension (Hokanson et al. 1996). In management of hypertriglyceridemia various therapies have been selected. A systematic search of randomized controlled trials, comparing any lipid-lowering intervention with placebo or usual diet with respect to mortality, resulted in conclusion that statins and n-3 polyunsaturated fatty acids (PUFA) are the most favorable lipid-lowering interventions with reduced risks of overall and cardiac mortality (Studer et al. 2005). Numerous other studies have shown that in HTG treatment statins and a diet rich in omega-3 polyunsaturated fatty acids (particularly docosahexaenoic acid and eicosapentaenoic acid) lower lipid levels in plasma and have an important impact in primary and secondary prevention of cardiovascular disease and atherosclerosis as well.

For better understanding of pathophysiological processes leading to cardiovascular events as a consequence of hyperlipidemia, several experimental 
models have been intensively studied. One of these alternatives, known as Prague hereditary hypertriglyceridemic (hHTG) rats, was developed as a model of human hypertriglyceridemia (Vrána and Kazdová 1990). A large number of studies have revealed that Prague hHTG rats represent a suitable model for the study of metabolic disturbances in relation to blood pressure. Numerous abnormalities of blood pressure regulation as well as alterations in the structure and function of the cardiovascular system were found in this model (for review see Zicha et al. 2006). The Prague hHTG rats showed a significant increase of diastolic blood pressure accompanied with hypertrophy of the left ventricle (Klimeš et al. 1997). In other studies increase of systolic blood pressure (Šimko et al. 2002) and hypertrophy of the right ventricle were documented (Šimko et al. 2005). The aorta is also altered in hHTG rats, as documented by quantitative and qualitative changes of endothelium and connexin 43 (Dlugosova et al. 2009). Besides the increased pressure overload also the altered retention of sodium and subsequent enlargement of circulating volume may be co-responsible for the development of cardiac hypertrophy (Klimeš et al. 1997). The kidneys of hypertriglyceridemic rats were more susceptible to cyclosporin-induced nephrotoxicity which was reduced in hHTG rats by PUFA (Bohdanecká et al. 1999). Administration of PUFA and also atorvastatin resulted in antiarrhythmic effect via protection of cardiomyocytes and cell-to-cell junction integrity (Bacova et al. 2010).

The mammalian kidney plays a crucial role in maintaining the extracellular homeostasis of sodium ions. One of the key systems involved in this process is renal $\mathrm{Na}, \mathrm{K}-\mathrm{ATPase}$ or so called sodium pump which transports $3 \mathrm{Na}^{+}$ions out of the cell and $2 \mathrm{~K}^{+}$ions into the cell using the energy derived from hydrolysis of one molecule of ATP. Previous studies have documented that $\mathrm{Na}, \mathrm{K}-$ ATPase is sensitive to the administration of PUFA (Gerbi et al. 1997, Djemli-Shipkolye et al. 2002). Administration of atorvastatin or simvastatin to hyperlipidemic patients also increased the activity of $\mathrm{Na}, \mathrm{K}-\mathrm{ATPase}$ in erythrocytes (Broncel et al. 1997).

Trying to characterize the utilization of ATP and $\mathrm{Na}^{+}$-binding properties of renal $\mathrm{Na}, \mathrm{K}$-ATPase during hypertriglyceridemia and its treatment with PUFA and atorvastatin, the present study was designed to investigate the kinetic properties of the enzyme in male and female hHTG rats.

\section{Methods}

\section{Animal model}

Experiments were performed on adult Wistar rats and rats with hereditary hypertriglyceridemia (HTG) of both genders.

At the beginning of experiments, 3-month-old Wistar and HTG animals of both genders were divided into 3 groups ( $\mathrm{n}=8$ in each experimental group): Wistar and HTG rats fed with $n-3$ polyunsaturated fatty acid diet isolated from fish oil (eicosapentaenoic acid and docosahexaenoic acid, Vesterålen, Norway, $30 \mathrm{mg} \cdot \mathrm{day}^{-1}$ ) for two months (WfFO - Wistar females, HfFO - HTG females, WmFO - Wistar males, HmFO - HTG males), Wistar and HTG rats treated with atorvastatin (Zentiva, Slovakia, $0.5 \mathrm{mg} \cdot 100 \mathrm{~g}^{-1}$ body weight per day) for two months (WfA, HfA, WmA, HmA), and untreated Wistar and HTG control rats (WfC, $\mathrm{HfC}, \mathrm{WmC}, \mathrm{HmC}$ ). All rats were allowed free access to food and drinking water. The animal room was air-conditioned and the environment was continually monitored for the temperature of $23 \pm 1{ }^{\circ} \mathrm{C}$ with relative humidity of $55 \pm 10 \%$. At the end of experiment, the rats were anesthetized by thiopental anesthesia, the excised kidneys were immediately frozen in liquid nitrogen and stored for further investigations of $\mathrm{Na}, \mathrm{K}-\mathrm{ATPase}$ properties. All experiments were approved by the Veterinary Council of the Slovak Republic (Decree No. 289, part 139, July 9th 2003) and were conform to Principles of Laboratory Animal Care (NIH publication 83-25, revised 1985).

\section{Sample isolation}

The plasmalemmal membrane fraction from rat kidney was isolated according to Jorgensen (1974) with slight modifications. Briefly, the renal tissue was homogenized in cold isolation medium containing in mmol. $1^{-1}: 250$ sucrose, 25 imidazol, 1 EDTA (pH 7.4) using a tissue disruptor $(3 \times 10 \mathrm{sec}$ at a setting of 4 , Polytron PT-20). The homogenate was centrifuged at $6000 \mathrm{~g}$ for $15 \mathrm{~min}$. The sediment was re-homogenized and centrifuged again at $6000 \mathrm{~g}$ for $15 \mathrm{~min}$. The collected supernatants from both centrifugations were recentrifuged at $48000 \mathrm{~g}$ for $30 \mathrm{~min}$ and the final sediment was re-suspended in the isolation medium. An aliquot was removed for determination of proteins by the method of Lowry et al. (1951) using bovine serum albumin as standard. 


\section{Enzyme kinetics}

ATP-kinetics of Na,K-ATPase was estimated at the temperature of $37{ }^{\circ} \mathrm{C}$ measuring the hydrolysis of ATP by $10 \mu \mathrm{g}$ plasmalemmal proteins in the presence of increasing concentrations of the substrate ATP (0.16-8.0 $\left.\mathrm{mmol} \cdot \mathrm{l}^{-1}\right)$. The total volume of the medium was $0.5 \mathrm{ml}$ containing (in mmol. $\mathrm{l}^{-1}$ ): $\mathrm{MgCl}_{2} 4, \mathrm{KCl} 10, \mathrm{NaCl} 100$ and imidazole 50 (pH 7.4). After $20 \mathrm{~min}$ of pre-incubation in substrate-free medium, the reaction was started by addition of ATP and after $20 \mathrm{~min}$ the reaction was stopped by addition of $0.3 \mathrm{ml} 12 \%$ ice-cold solution of trichloroacetic acid. The liberated inorganic phosphorus was determined according to Taussky and Shorr (1953). In order to establish the Na,K-ATPase activity, the ATP hydrolysis that occurred in the presence of $\mathrm{Mg}^{2+}$ only was subtracted. The Na,K-ATPase kinetics for cofactor $\mathrm{Na}^{+}$ was determined by the same method, in the presence of increasing concentrations of $\mathrm{NaCl}\left(2.0-100.0 \mathrm{mmol} \cdot \mathrm{l}^{-1}\right)$. The amount of ATP was constant $\left(8 \mathrm{mmol} \cdot \mathrm{l}^{-1}\right)$. The kinetic parameters $\mathrm{V}_{\text {max }}, \mathrm{K}_{\mathrm{m}}, \mathrm{K}_{\mathrm{Na}}$ were evaluated from the obtained data by direct nonlinear regression. The parameter $\mathrm{V}_{\max }$ represents the maximal velocity, $\mathrm{K}_{\mathrm{m}}$ and $\mathrm{K}_{\mathrm{Na}}$ values represent the concentrations of ATP or $\mathrm{Na}^{+}$ necessary for half maximal activation of the enzyme.

\section{Statistical analysis}

All results were expressed as mean \pm S.E.M. The significance of differences between the individual groups was determined using the one-way analysis of variance (ANOVA) by Student-Newman-Keuls test. A value of $\mathrm{p}<0.05$ was regarded as significant.

\section{Results}

When activating renal $\mathrm{Na}, \mathrm{K}-\mathrm{ATPase}$ with increasing concentrations of substrate, its activity was higher in hHTG groups throughout the applied range of ATP concentrations as compared to Wistar groups (Fig. 1). This effect was observed in female as well as in male groups. Evaluation of the data by nonlinear regression resulted in higher $\mathrm{V}_{\max }$ value in the $\mathrm{WfC}$ group by $23 \%$ as compared to the $\mathrm{WmC}$ group. Similar gender specificity was observed also in hHTG animals where the $\mathrm{V}_{\max }$ value in the HfC group was by $18 \%$ higher as compared to the HmC group. Hypertriglyceridemia itself induced a significant increase of $\mathrm{V}_{\max }$ value in both genders, representing $25 \%$ in males and $21 \%$ in females. The $\mathrm{K}_{\mathrm{m}}$ value remained similar in all four compared groups (Table 1).
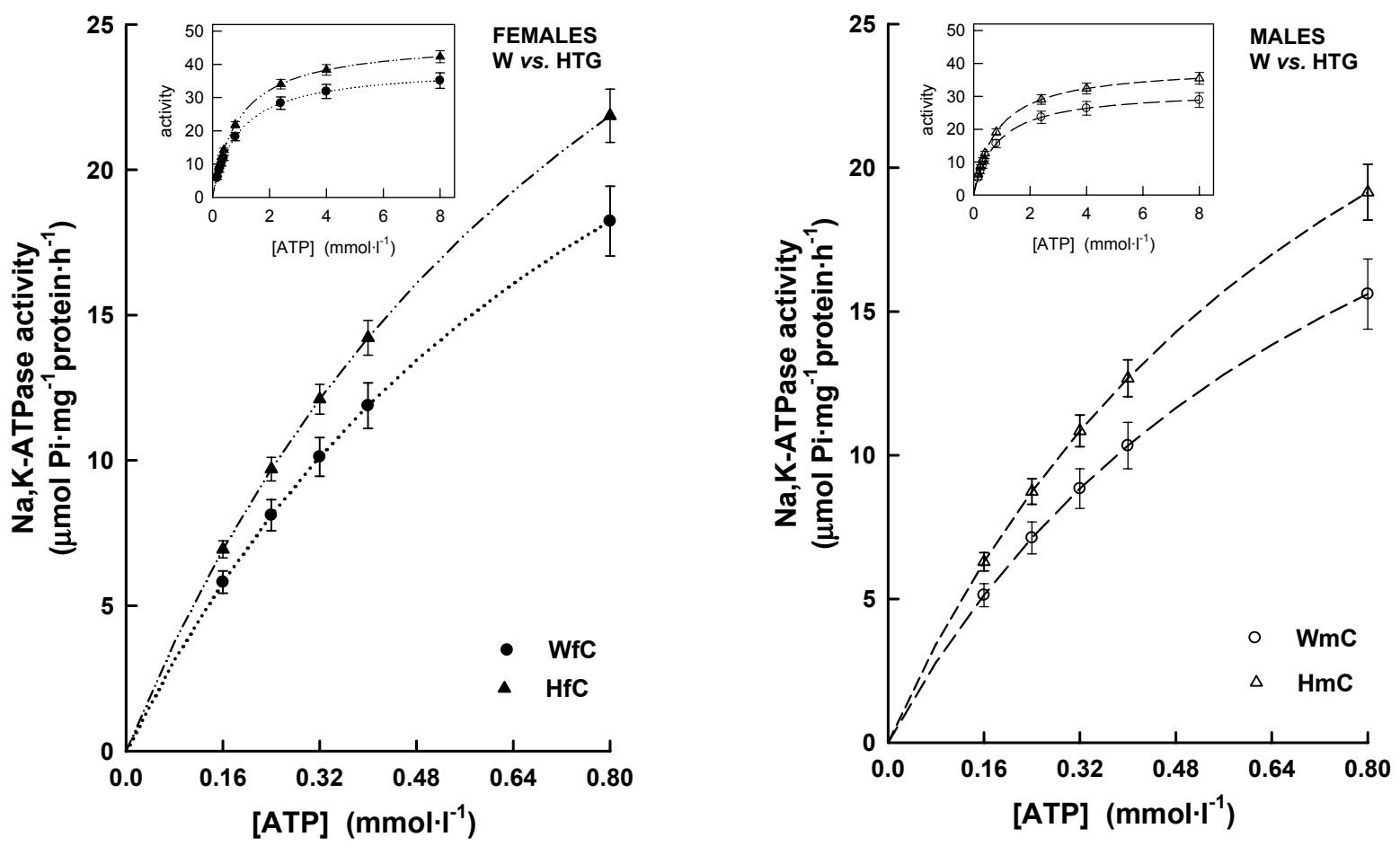

Fig. 1. Activation of renal $\mathrm{Na}, \mathrm{K}-\mathrm{ATPase}$ by low concentrations of substrate ATP in Wistar rats and hypertriglyceridemic (hHTG) rats divided into the following groups: left panel control female Wistar rats (WfC), control female hHTG rats (HfC), right panel control male Wistar rats $(\mathrm{WmC})$, control male hHTG rats $(\mathrm{HmC})$. Insert: activation of the enzyme in the whole range of ATP concentrations. 
Table 1. Kinetic parameters of renal $\mathrm{Na}$, K-ATPase during activation with ATP and $\mathrm{NaCl}$ in Wistar rats and hypertriglyceridemic (hHTG) rats divided into the following groups: control female Wistar rats (WfC), control female hHTG rats (HfC), control male Wistar rats (WmC), control male $\mathrm{hHTG}$ rats $(\mathrm{HmC})$.

\begin{tabular}{lcccc}
\hline Groups of rats & $\begin{array}{c}\mathbf{V}_{\mathbf{m a x}} \\
\text { ATP-kinetics }\end{array}$ & $\mathbf{K}_{\mathbf{m}}$ & $\begin{array}{c}\mathbf{V}_{\max } \\
\text { Na-kinetics }\end{array}$ & $\mathbf{K}_{\mathbf{N a}}$ \\
\hline$W m C$ & $31.9 \pm 2.5$ & $0.83 \pm 0.04$ & $33.5 \pm 2.1$ & $11.25 \pm 0.59$ \\
$W f C$ & $39.1 \pm 2.6^{\mathrm{a}}$ & $0.92 \pm 0.04$ & $38.9 \pm 2.1^{\mathrm{a}}$ & $13.96 \pm 0.75^{\mathrm{a}}$ \\
$H m C$ & $39.9 \pm 2.0^{\mathrm{a}}$ & $0.84 \pm 0.05$ & $40.9 \pm 1.6^{\mathrm{a}}$ & $10.14 \pm 0.34$ \\
$H f C$ & $47.2 \pm 2.0^{\mathrm{b}, \mathrm{c}}$ & $0.93 \pm 0.03$ & $47.4 \pm 2.3^{\mathrm{b}, \mathrm{c}}$ & $11.16 \pm 0.43^{\mathrm{b}}$ \\
\hline
\end{tabular}

Data represent means \pm S.E.M., $n=8$ in each group. a: $p<0.05$ as compared to the WmC group, b: $p<0.05$ as compared to the WfC group, c: $p<0.05$ as compared to the $\mathrm{HmC}$ group.
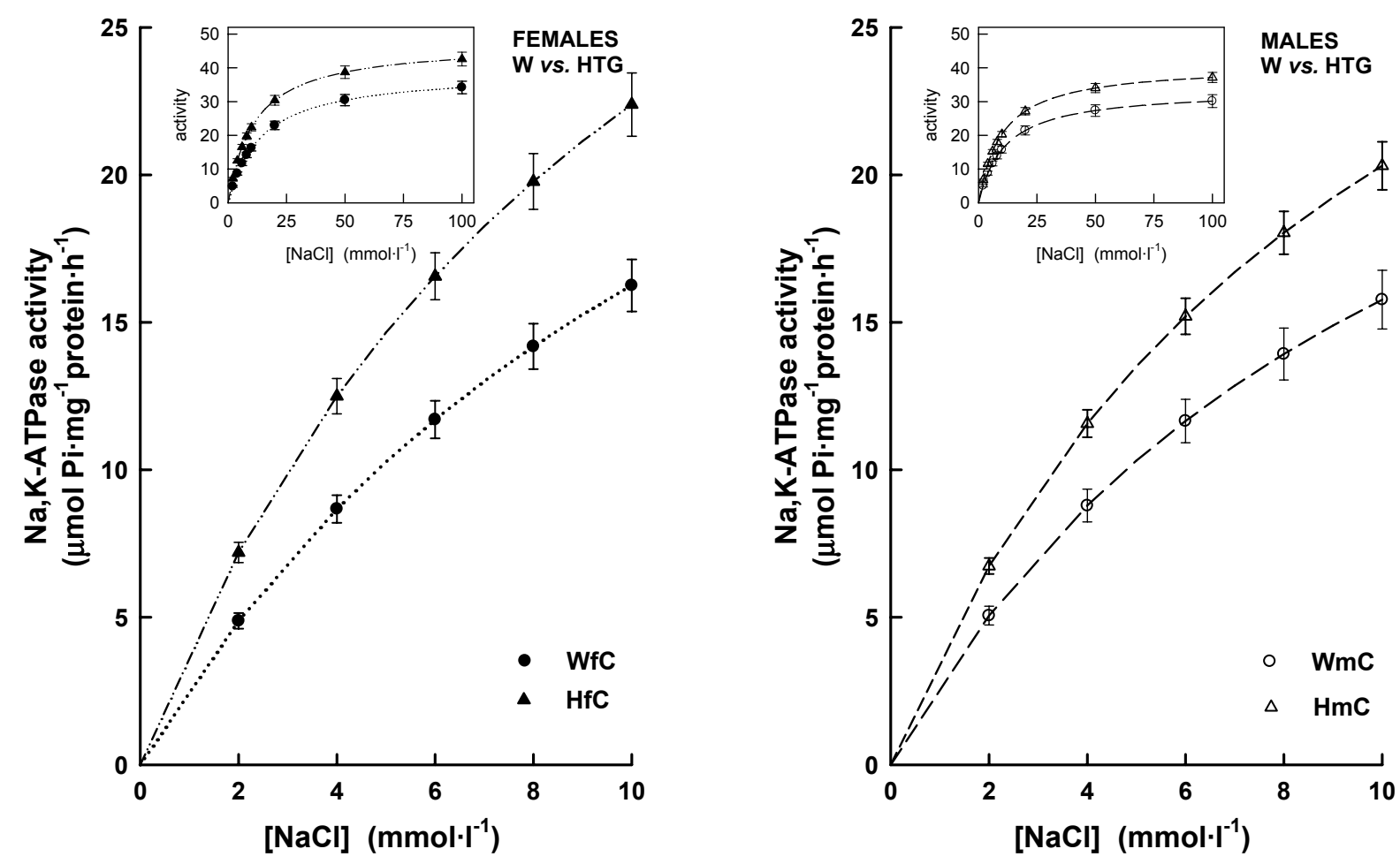

Fig. 2. Activation of renal $\mathrm{Na}, \mathrm{K}-\mathrm{ATPase}$ by low concentrations of $\mathrm{NaCl}$ in Wistar rats $(\mathrm{W}$ ) and hypertriglyceridemic (hHTG) rats divided into the following groups: left panel $\sim$ control female Wistar rats (WfC), control female hHTG rats (HfC), right panel $\sim$ control male Wistar rats $(\mathrm{WmC})$, control male $\mathrm{hHTG}$ rats $(\mathrm{HmC})$. Insert: activation of the enzyme in the whole range of $\mathrm{NaCl}$ concentrations.

Activation of the enzyme with increasing concentrations of cofactor $\mathrm{Na}^{+}$resulted again in higher activity in hHTG groups throughout the applied range of $\mathrm{NaCl}$ concentrations as compared to Wistar groups in both genders (Fig. 2). Evaluation of kinetic parameters revealed higher $\mathrm{V}_{\max }$ value in the $\mathrm{WfC}$ group by $16 \%$ as compared to the $\mathrm{WmC}$ group. Similar gender specificity was observed also in hHTG animals where the $\mathrm{V}_{\max }$ value in the HfC group was by $16 \%$ higher as compared to the $\mathrm{HmC}$ group. Hypertriglyceridemia itself induced a significant increase of $\mathrm{V}_{\max }$ value in both genders representing $22 \%$. The $\mathrm{K}_{\mathrm{Na}}$ value showed gender specificity in Wistar rats, where this parameter was higher by $24 \%$ in $\mathrm{WfC}$ as compared to the $\mathrm{WmC}$ group (Table 1).

Administration of fish oil to Wistar females induced a slight increase of $\mathrm{Na}, \mathrm{K}$-ATPase activities in the presence of low concentrations of ATP, but in the presence of higher concentrations exceeding $2 \mathrm{mmol}^{-1}$ ATP the activities were slightly lower as compared to untreated controls (Fig. 3). This biphasic effect of fish oil administration was reflected in decrease of $\mathrm{K}_{\mathrm{m}}$ value by $15 \%$ in WfFO as compared to WfC group (Table 2). In Wistar males the enzyme activity was similar throughout the applied concentration range of ATP (Fig. 3) without any alterations in kinetic parameters (Table 2). 

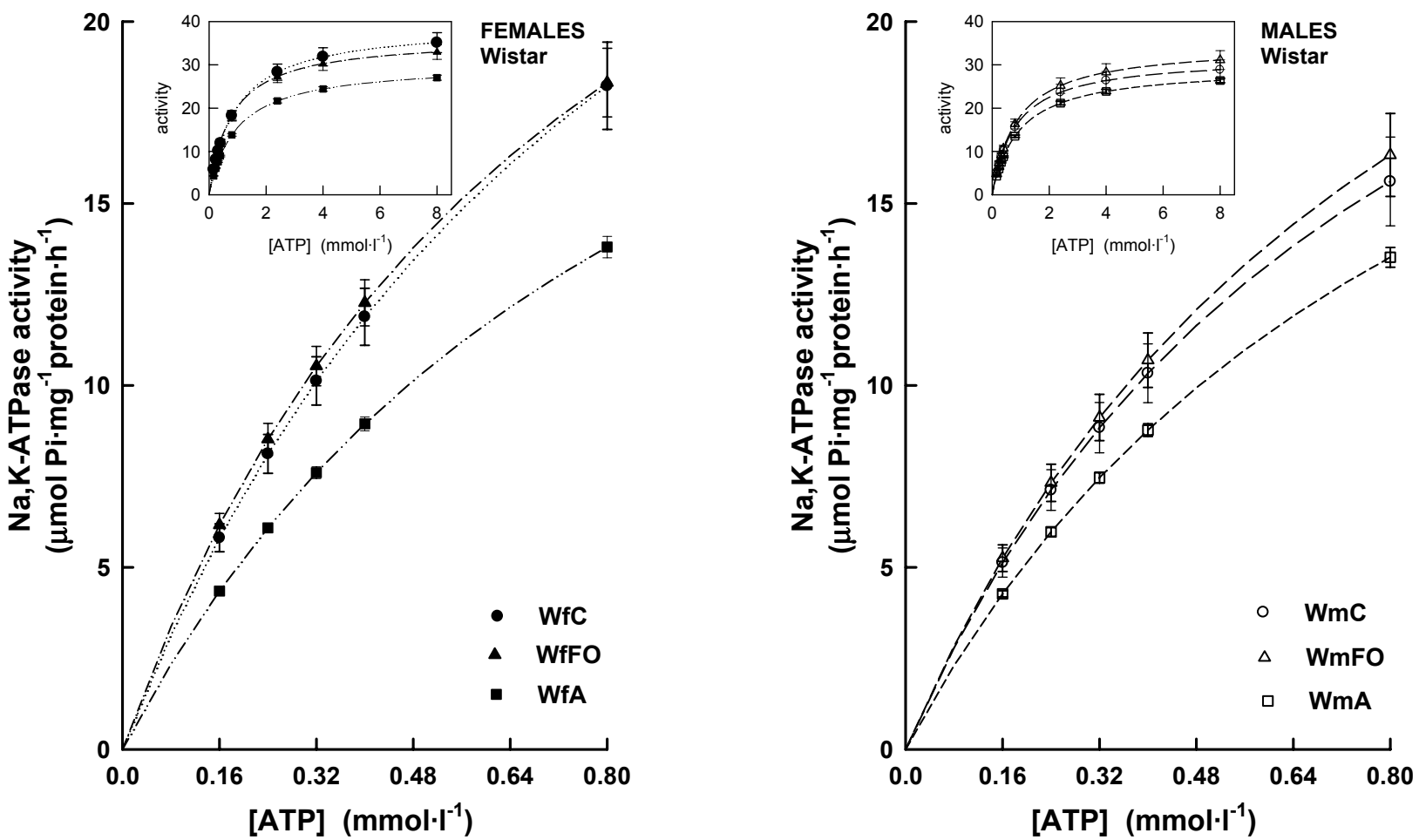

Fig. 3. Effect of in vivo administration of fish oil and atorvastatin on the activation of renal Na,K-ATPase by low concentrations of substrate ATP in Wistar rats divided into the following groups: left panel control female rats (WfC), female rats treated with fish oil (WfFO), female rats treated with atorvastatin (WfA), right panel control male rats $(\mathrm{WmC})$, male rats treated with fish oil $(\mathrm{WmFO})$, male rats treated with atorvastatin (WmA). Insert: activation of the enzyme in the whole range of ATP concentrations.

Table 2. Effect of in vivo administration of fish oil and atorvastatin on kinetic parameters of renal Na,K-ATPase during activation with ATP and $\mathrm{NaCl}$ in Wistar rats divided into the following groups: control male rats $(\mathrm{WmC})$, male rats treated with fish oil (WmFO), male rats treated with atorvastatin $(\mathrm{WmA})$, control female rats $(\mathrm{WfC})$, female rats treated with fish oil (WfFO), male rats treated with atorvastatin (WfA).

\begin{tabular}{lcccc}
\hline Groups of rats & $\begin{array}{c}\mathbf{V}_{\max } \\
\text { ATP-kinetics }\end{array}$ & $\mathbf{K}_{\mathbf{m}}$ & $\begin{array}{c}\mathbf{V}_{\max } \\
\text { Na-kinetics }\end{array}$ & $\mathbf{K}_{\mathbf{N a}}$ \\
\hline$W m C$ & $31.9 \pm 2.5$ & $0.83 \pm 0.04$ & $33.5 \pm 2.1$ & $11.25 \pm 0.59$ \\
$W m F O$ & $34.6 \pm 2.4$ & $0.89 \pm 0.05$ & $39.3 \pm 2.0^{\mathrm{a}}$ & $14.10 \pm 0.93^{\mathrm{a}}$ \\
$W m A$ & $29.5 \pm 0.6$ & $0.94 \pm 0.04$ & $31.5 \pm 0.1$ & $13.78 \pm 0.62^{\mathrm{a}}$ \\
$W f C$ & $39.1 \pm 2.6^{\mathrm{a}}$ & $0.92 \pm 0.04$ & $38.9 \pm 2.1^{\mathrm{a}}$ & $13.96 \pm 0.75^{\mathrm{a}}$ \\
$W f F O$ & $36.1 \pm 1.9$ & $0.78 \pm 0.04^{\mathrm{b}}$ & $39.6 \pm 2.3$ & $11.61 \pm 0.39^{\mathrm{b}}$ \\
$W f A$ & $30.2 \pm 0.6^{\mathrm{b}}$ & $0.95 \pm 0.05^{\mathrm{c}}$ & $30.8 \pm 1.1^{\mathrm{b}}$ & $11.02 \pm 0.75^{\mathrm{b}}$ \\
\hline
\end{tabular}

Data represent means \pm S.E.M., $n=8$ in each group. a: $p<0.05$ as compared to the WmC group, $b: p<0.05$ as compared to the WfC group, c: $p<0.05$ as compared to the WfFO group.

Administration of atorvastatin to Wistar rats was followed by decreased enzyme activities throughout the whole concentration range of ATP in both genders (Fig. 3). Evaluation of kinetics parameters resulted in significant decrease of $\mathrm{V}_{\max }$ value in females only, as shown by $23 \%$ decrease in WfA compared to the WfC group (Table 2).

During activation of renal Na,K-ATPase with increasing concentrations of $\mathrm{NaCl}$, a slight stimulation of the enzyme activity was observed in Wistar females treated with fish oil. This effect we observed in the presence of lower concentrations below $10 \mathrm{mmol}^{-1}$ of $\mathrm{NaCl}$, above this concentration the effect was lost (Fig. 4). Evaluation of this effect revealed unchanged $\mathrm{V}_{\max }$ with decreased $\mathrm{K}_{\mathrm{Na}}$ value by $17 \%$ in the $\mathrm{WfFO}$ as compared to the WfC group (Table 2). Administration of 
fish oil to Wistar males induced again a slight stimulation of $\mathrm{Na}, \mathrm{K}-\mathrm{ATPa}$ e activity but the stimulatory effect increased stepwise with increasing concentration of $\mathrm{NaCl}$

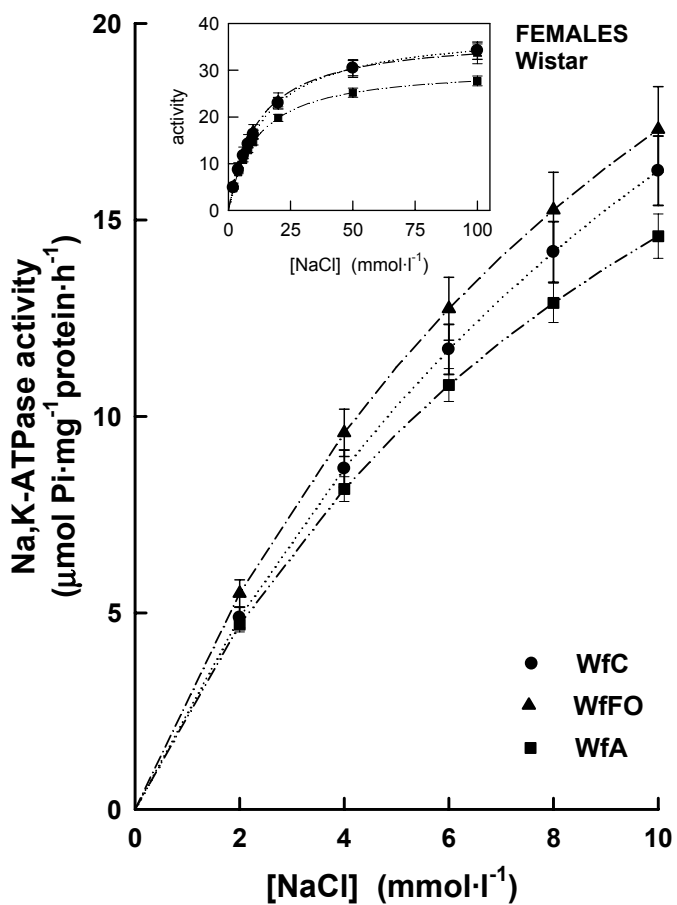

(Fig. 4) resulting in increased values of $\mathrm{V}_{\max }$ by $17 \%$ and $\mathrm{K}_{\mathrm{Na}}$ by $25 \%$ in $\mathrm{WmFO}$ as compared to the $\mathrm{WmC}$ group (Table 2).

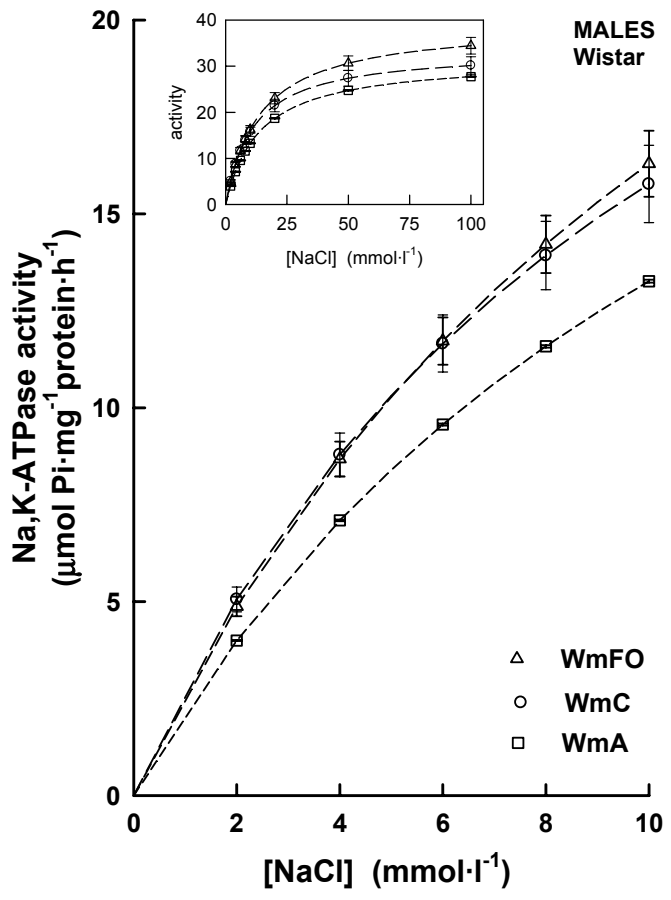

Fig. 4. Effect of in vivo administration of fish oil and atorvastatin on the activation of renal $\mathrm{Na}, \mathrm{K}-\mathrm{ATPase}$ by low concentrations of $\mathrm{NaCl}$ in Wistar rats divided in the following groups: left panel control female rats $(\mathrm{WfC})$, female rats treated with fish oil (WfFO), female rats treated with atorvastatin $(\mathrm{WfA})$, right panel control male rats $(\mathrm{WmC})$, male rats treated with fish oil $(\mathrm{WmFO})$, male rats treated with atorvastatin $(\mathrm{WmA})$. Insert: activation of the enzyme in the whole range of $\mathrm{NaCl}$ concentrations.
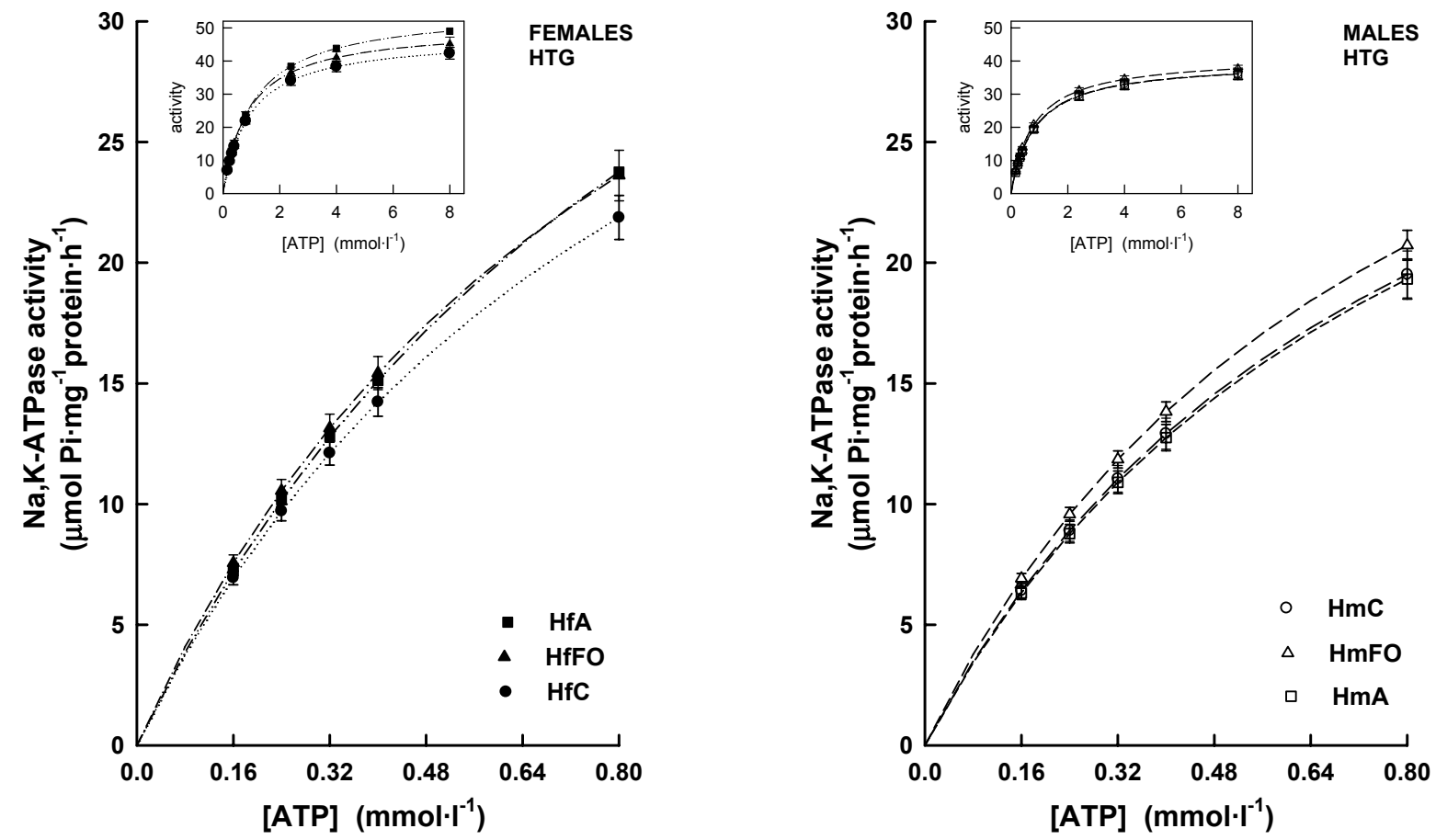

Fig. 5. Effect of in vivo administration of fish oil and atorvastatin on the activation of renal $\mathrm{Na}, \mathrm{K}$-ATPase by low concentrations of substrate ATP in hypertriglyceridemic (hHTG) rats divided into the following groups: left panel $\sim$ control female rats (HfC), female rats treated with fish oil (HfFO), female rats treated with atorvastatin ( $\mathrm{HfA}$ ), right panel control male rats ( $\mathrm{HmC})$, male rats treated with fish oil (HmFO), male rats treated with atorvastatin $(\mathrm{HmA})$. Insert: activation of the enzyme in the whole range of ATP concentrations. 
Table 3. Effect of in vivo administration of fish oil and atorvastatin on kinetic parameters of renal Na,K-ATPase during activation with ATP and $\mathrm{NaCl}$ in hypertriglyceridemic (hHTG) rats divided into the following groups: control male rats (HmC), male rats treated with fish oil $(\mathrm{HmFO})$, male rats treated with atorvastatin $(\mathrm{HmA})$, control female rats $(\mathrm{HfC})$, female rats treated with fish oil $(\mathrm{HfFO})$, male rats treated with atorvastatin (HfA).

\begin{tabular}{lcccc}
\hline Groups of rats & $\begin{array}{c}\mathbf{V}_{\mathbf{m a x}} \\
\text { ATP-kinetics }\end{array}$ & $\mathbf{K}_{\mathbf{m}}$ & $\begin{array}{c}\mathbf{V}_{\mathbf{m a x}} \\
\text { Na-kinetics }\end{array}$ & $\mathbf{K}_{\mathbf{N a}}$ \\
\hline$H m C$ & $39.9 \pm 2.0$ & $0,84 \pm 0.05$ & $40.9 \pm 1.6$ & $10.14 \pm 0.34$ \\
$H m F O$ & $41.4 \pm 1.2$ & $0.80 \pm 0.03$ & $40.7 \pm 1.4$ & $10.65 \pm 033$ \\
$H m A$ & $39.9 \pm 1.7$ & $0.85 \pm 0.03$ & $41.5 \pm 1.4$ & $11.36 \pm 0.29^{\mathrm{a}}$ \\
$H f C$ & $47.2 \pm 2.0^{\mathrm{a}}$ & $0.93 \pm 0.03$ & $47.4 \pm 2.3^{\mathrm{a}}$ & $11.16 \pm 0.43$ \\
$H f F O$ & $50.3 \pm 2.2^{\mathrm{b}}$ & $0.91 \pm 0.09$ & $50.3 \pm 2.3^{\mathrm{b}}$ & $9.94 \pm 0.42^{\mathrm{d}}$ \\
$H f A$ & $55.5 \pm 1.2^{\mathrm{c}, \mathrm{d}}$ & $1.07 \pm 0.04^{\mathrm{c}, \mathrm{d}}$ & $54.1 \pm 0.9^{\mathrm{c}, \mathrm{d}}$ & $11.30 \pm 0.63$ \\
\hline
\end{tabular}

Data represent means \pm S.E.M., $n=8$ in each group. a: $p<0.05$ as compared to the HmC group, $b: p<0.05$ as compared to the HmFO group, c: $p<0.05$ as compared to the HmA group, $d: p<0.05$ as compared to the HfC group.
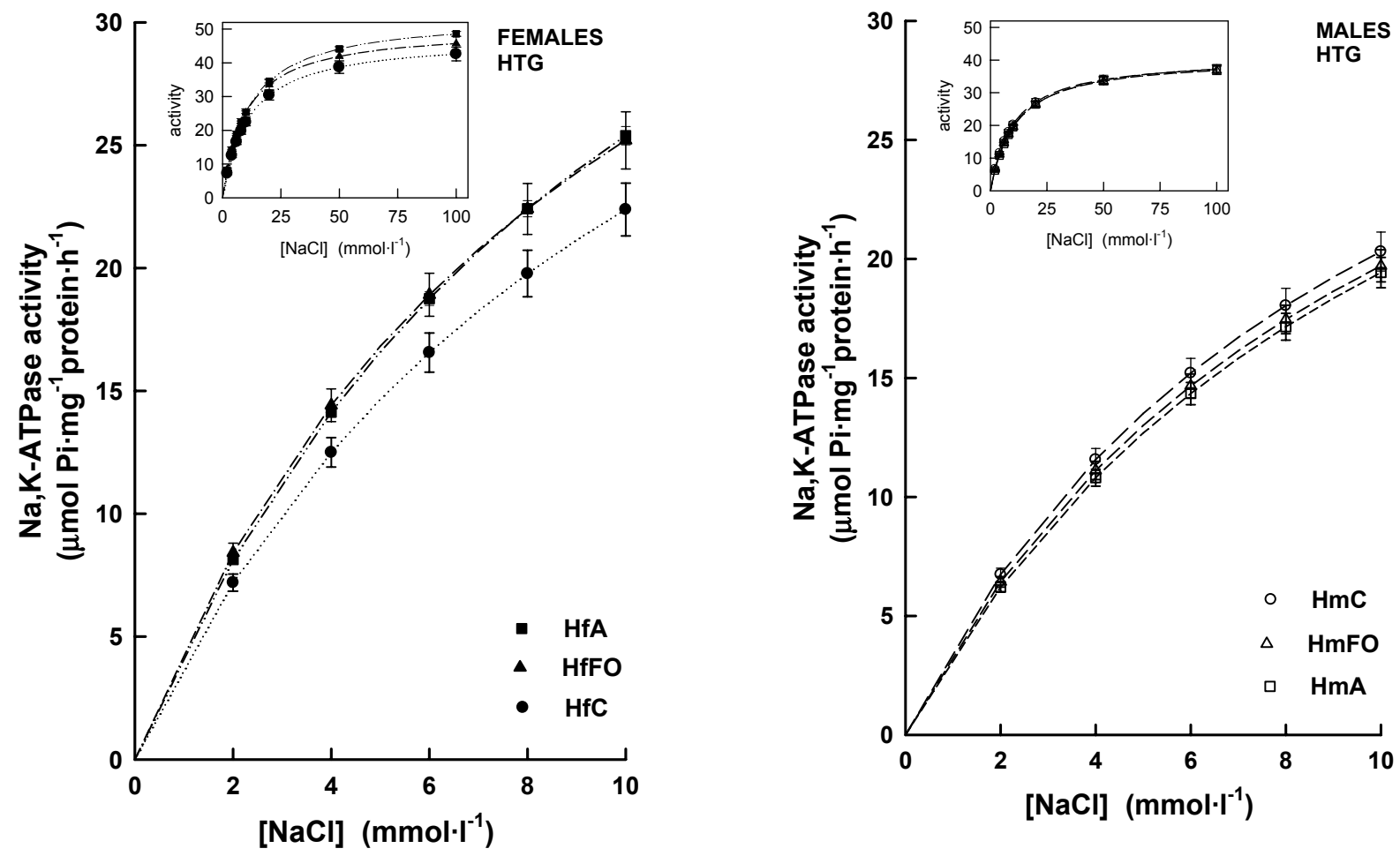

Fig. 6. Effect of in vivo administration of fish oil and atorvastatin on the activation of renal $\mathrm{Na}, \mathrm{K}-\mathrm{ATPase}$ by low concentrations of $\mathrm{NaCl}$ in hypertriglyceridemic (hHTG) rats divided into the following groups: left panel control female rats (HfC), female rats treated with fish oil (HfFO), female rats treated with atorvastatin ( $\mathrm{HfA})$, right panel control male rats $(\mathrm{HmC})$, male rats treated with fish oil $(\mathrm{HmFO})$, male rats treated with atorvastatin $\mathrm{s}(\mathrm{HmA})$. Insert: activation of the enzyme in the whole range of $\mathrm{NaCl}$ concentrations.

Administration of atorvastatin to Wistar rats was followed by decreased enzyme activities throughout the whole concentration range of $\mathrm{NaCl}$ in both genders (Fig. 4). Evaluation of kinetics parameters resulted in significant decrease of $\mathrm{V}_{\max }$ value by $21 \%$ in WfA as compared to the WfC group. The $\mathrm{K}_{\mathrm{Na}}$ value was significantly increased by $22 \%$ in males, however in females the value was decreased by $21 \%$, as compared to respective controls (Table 2).

Administration of fish oil to hHTG rats induced a slight increase of $\mathrm{Na}, \mathrm{K}$-ATPase activities throughout the investigated concentration range of ATP in both genders as compared to untreated animals (Fig. 5), however this slight effect was not reflected either in changes of $V_{\max }$ or of $K_{m}$ values (Table 3).

Administration of atorvastatin to hHTG rats 
induced a slight stimulation in female rats only (Fig. 5), resulting in an $18 \%$ increase of $\mathrm{V}_{\max }$ and $15 \%$ of $\mathrm{K}_{\mathrm{m}}$ value (Table 3).

When activating renal Na,K-ATPase with increasing concentrations of $\mathrm{NaCl}$, we observed a slight stimulation of the enzyme activity only in females of hHTG animals treated with fish oil (Fig. 6). Evaluation of this effect revealed significant decrease of $\mathrm{K}_{\mathrm{Na}}$ value by $11 \%$ in HfFO as compared to the HfC group (Table 3).

Administration of atorvastatin to hHTG female rats was followed by increased enzyme activities throughout the whole concentration range of $\mathrm{NaCl}$ (Fig. 6), resulting in $14 \%$ increase of $\mathrm{V}_{\max }$ value in HfA as compared to the HfC group (Table 3). On the other hand, in males we observed a slight decrease of enzyme activity below $10 \mathrm{mmol} \cdot \mathrm{l}^{-1}$ concentration of $\mathrm{NaCl}$ (Fig. 6) resulting in a small but statistically significant increase of $\mathrm{K}_{\mathrm{Na}}$ value by $12 \%$ in $\mathrm{HmA}$ as compared to the $\mathrm{HmC}$ group (Table 3).

\section{Discussion}

There are cumulative data indicating that sodium transport across the cell membrane is gender dependent (Grikiniene et al. 2004). Healthy females showed a significantly lower intracellular concentration of $\mathrm{Na}^{+}$ (Smith et al. 1988, Taylor et al. 1991) as compared to males. Gender-related differences in intracellular $\mathrm{Na}^{+}$ concentration result most likely from differences in the function of sodium transport systems including $\mathrm{Na}, \mathrm{K}$ ATPase. This hypothesis is confirmed also by our present study, documenting increased activity of renal $\mathrm{Na}, \mathrm{K}$ ATPase in control female Wistar rats. This is in agreement with previous data of Quintas et al. (1997). However, some other experimental studies documented similarity in activities and expression of renal $\mathrm{Na}, \mathrm{K}$ ATPase during normal physiological conditions in both genders (Fekete et al. 2004, 2006).

Our data provided evidence that in the situation of pathophysiological overload the activity of renal $\mathrm{Na}, \mathrm{K}-\mathrm{ATPase}$ was again increased in females as comaperd to male hHTG rats. The increased activity of renal Na,K-ATPase in hHTG females may be explained by a hypothetically higher presence of the active enzyme molecules in the renal tissue in females as compared to males. This hypothesis is supported by our data concerning the increased $\mathrm{V}_{\max }$ value in both types of enzyme kinetics in all female groups as compared to respective male groups. This finding, suggesting better adaptation of the enzyme to pathophysiological overload in females, is supported by the observation of higher mRNA expression of Na,K-ATPase catalytic $\alpha_{1}$ subunit, as well as higher activity in female rats as compared to males after ischemia reperfusion injury in the kidney (Fekete et al. 2004). The sexual disparity of $\mathrm{Na}, \mathrm{K}-$ ATPase properties was demonstrated in various pathophysiological conditions also in other tissues, like the aorta (Palacios et al. 2006), heart (Vlkovičová et al. 2005) and erythrocytes (Smith et al. 1988).

The mechanism of the protection of $\mathrm{Na}, \mathrm{K}$ ATPase in females may be ascribed to estradiol, because it was previously shown that this hormone, besides other effects, stimulates directly and also indirectly the $\mathrm{Na}, \mathrm{K}-$ ATPase molecule in the cardiac tissue (Dzurba et al. 1997). This explanation is supported also by the finding that the significantly higher activity of the sodium pump is a consequence of estradiol-induced increase in $\mathrm{Na}, \mathrm{K}$ ATPase $\alpha 2$ subunit expression in the female aorta (Palacios et al. 2004) and $\alpha 1$ subunit expression in the female kidney (Fekete et al. 2004). Estradiol also stimulated $\mathrm{Na}, \mathrm{K}-\mathrm{ATPase}$ activity and the expression of $\alpha 1$ subunit via multiple signaling cascades, including phosphatidyl inositol-3 kinase and p42/44 mitogenactivated protein kinase in vascular smooth muscle (Sudar et al. 2008).

It is necessary to mention that renal $\mathrm{Na}, \mathrm{K}$ ATPase activity was higher in both genders of hHTG rats as compared to respective control Wistar groups. So the improved extrusion of intracellular sodium out of the cell as a consequence of increased $\mathrm{Na}, \mathrm{K}$-ATPase activity documented in the present study, may be the reason for increased retention of sodium in hHTG rats, as shown by Klimeš et al. (1997).

Previous studies reported that the Na,K-ATPase was sensitive to the administration of $n-3$ polyunsaturated fatty acids (PUFA). The effect of fatty acids was dependent on physiological or pathophysiological conditions and it showed also tissue dependence. The positive effect of PUFA on Na,K-ATPase was documented during diabetes in red blood cells (DjemliShipkolye et al. 2002), in hearts (Gerbi et al. 1997) and in sciatic nerves (Gerbi et al. 1999). On the other hand, Djemli-Shipkolye et al. (2002) observed a negative effect of PUFA on Na,K-ATPase in sciatic nerves in diabetic as well as in healthy rats. It should be mentioned that all previous studies were carried out exclusively on males.

It is known that $\mathrm{Na}, \mathrm{K}-\mathrm{ATPase}$ reveals different properties in males and females, as discussed previously. 
Therefore in our study we tried to broaden the knowledge about the effect of PUFA from the view of possible gender specificity. Our new data suggest a gender specific influence of PUFA on renal Na,K-ATPase. In Wistar female rats, fish oil improved the enzyme affinity to ATP and $\mathrm{Na}^{+}$, as indicated by lowered values of $\mathrm{K}_{\mathrm{m}}$ and $\mathrm{K}_{\mathrm{Na}}$. In Wistar males fish oil caused deterioration of the enzyme in the vicinity of the $\mathrm{Na}^{+}$-binding site, as revealed from the increased $\mathrm{K}_{\mathrm{Na}}$ value. In hHTG rats fish oil induced a significant effect only in females in the vicinity of the sodium binding sites, resulting in improved affinity, as documented by a lower value of $\mathrm{K}_{\mathrm{Na}}$. Our data indicate that renal $\mathrm{Na}, \mathrm{K}-\mathrm{ATPase}$ in healthy and also in hypertriglyceridemic female rats seems to be more sensitive to the protective effect of PUFA administration.

Atorvastatin did not influence the vicinity of the ATP binding site in Wistar males nor in Wistar females, as suggested by unchanged $\mathrm{K}_{\mathrm{m}}$ values. In the vicinity of the $\mathrm{Na}^{+}$binding site of $\mathrm{Na}, \mathrm{K}-\mathrm{ATPase}$ in male Wistar rats, atorvastatin induced probably conformational changes, resulting in deteriorated affinity to sodium, as suggested by increased value of $\mathrm{K}_{\mathrm{Na}}$. Concerning Wistar female rats, atorvastatin reduced the number of active $\mathrm{Na}, \mathrm{K}$ ATPase molecules as indicated by the lowered $V_{\max }$ value for both types of enzyme activation. This finding may suggest a decrease of transmembraneous transport of sodium out of the cell as a consequence of decreased $\mathrm{Na}$,K-ATPase activity, presumably followed by lowered retention of sodium in normotensive Wistar rats.

In male hypertriglyceridemic rats atorvastatin did not affect the functional properties of renal $\mathrm{Na}, \mathrm{K}$ ATPase, while in hHTG female rats it stimulated Na,KATPase in the whole concentration range of ATP or $\mathrm{Na}^{+}$. This effect is probably caused by an increased number of active enzyme molecules, as suggested by increased $\mathrm{V}_{\text {max }}$ value. So the enzyme in female rats treated with atorvastatin was capable to increase its activity also in the presence of high concentrations of ATP/ $\mathrm{Na}^{+}$, while the enzyme in untreated hHTG rats was already saturated. Administration of atorvastatin to healthy Wistar rats was followed by deteriorated properties of the renal $\mathrm{Na}, \mathrm{K}$ ATPase in both genders. While a positive effect was observed in the protection of renal Na,K-ATPase in hypertriglyceridemic rats, but this effect was strictly bound to females only.

In conclusion, treatment with fish oil or atorvastatin improved the functional properties of renal Na,K-ATPase in a gender specific manner, inducing probably improved extrusion of intracellular sodium out of the cell affecting thus the retention of sodium in hHTG females only.

\section{Conflict of Interest}

There is no conflict of interest.

\section{Acknowledgements}

The present study was supported by the Slovak Grant Agencies VEGA 2/0115/10 and by APVV 51-059505. The authors thank to Mrs. Z. Hradecká and Mrs. M. Zádorová for their careful technical assistance.

\section{References}

BACOVA B, RADOSINSKA J, KNEZL V, KOLENOVA L, WEISMANN P, NAVAROVA J, BARANCIK M, MITASIKOVA M, TRIBULOVA N: Omega-3 fatty acids and atorvastatin suppress ventricular fibrillation inducibility in hypertriglyceridemic rat hearts: implication of intracellular coupling protein, connexin-43. J Physiol Pharmacol 61: 717-723, 2010.

BOHDANECKÁ M, SCHUCK O, CHADIMOVÁ M, SEDIVÝ J, GLAGOLICOVÁ A, SKIBOVÁ J, KUNES J, DOBESOVÁ Z, STUCHLÍK M, VESELÁ J, KAZDOVÁ L: Nephrotoxicity of cyclosporine A in hereditary hypertriglyceridemic rats. Physiol Res 48: 437-443, 1999.

BRONCEL M, BALA A, KOLER-MICHALAK M, DUCHNOWICZ P, WOJSZNIS W, CHOJNOVSKA-JEZIERSKA $\mathrm{J}$ : Physicochemical modifications induced by statins therapy on human erythrocyte membranes. Wiad Lek 60: 321-328, 2007.

DJEMLI-SHIPKOLYE A, RACCAH D, PIERONI G, VAGUE P, COSTE TC, GERBI A: Differential effect of $\omega 3$ PUFA supplementations on $\mathrm{Na}, \mathrm{K}$-ATPase and Mg-ATPase activities: possible role of the membrane $\omega 6 / \omega 3$ ratio. J Membrane Biol 191: 37-47, 2002. 
DLUGOSOVA K, WEISMANN P, BERNATOVA I, SOTNIKOVA R, SLEZAK J, OKRUHLICOVA L: Omega -3 fatty acids and atorvastatin affect connexin 43 expression in the aorta of hereditary hypertriglyceridemic rats. Can J Physiol Pharmacol 87: 1074-1082, 2009.

FEKETE A, VANNAY A, VER A, RUSAI K, MULLER V, REUSZ G, TULASSAY T, SZABO AJ: Sex differences in heat shock protein 72 expression and localization in rats following renal ischemia-reperfusion injury. Am J Physiol Renal Physiol 291: 806-811, 2006.

FEKETE A, VANNAY A, VÉR A, VÁSÁRHELYI B, MÜLLER V, OUYANG N, REUSZ G, TULASSAY T, SZABÓ AJ: Sex differences in the alterations of $\mathrm{Na}^{+}, \mathrm{K}^{+}$-ATPase following ischaemia-reperfusion injury in the rat kidney. J Physiol 555: 471-480, 2004.

GERBI A, BARBEY O, RACCAH D, COSTE T, JAMME I, NOUVELOT A, OUAFIK L, LEVY S, VAGUE P, MAIXENT JM: Alteration of Na,K-ATPase isoenzymes in diabetic cardiomyopathy: effect of dietary supplementation with fish oil (n-3 fatty acids) in rats. Diabetologia 40: 496-505, 1997.

GERBI A, MAIXENT JM, ANSALDI JL, PIERLOVISI M, COSTE T, PELISSIER JF, VAGUE P, RACCAH D: Fish oil supplementation prevents diabetes-induced nerve conduction velocity and neuroanatomical changes in rats. J Nutr 129: 207-213, 1999.

GRIKINIENE J, VOLBEKAS V, STAKISAITIS D: Gender differences of sodium metabolism and hyponatremia as an adverse drug effect. Medicina (Kaunas) 40: 935-942, 2004.

HOKANSON JE, AUSTIN MA: Plasma triglyceride level is a risk factor for cardiovascular disease independent of high-density lipoprotein cholesterol level: a meta-analysis of population-based prospective studies. J Cardiovasc Risk 3: 213-219, 1996.

JORGENSEN PL: Purification and characterization of Na,K-ATPase: III. Purification from the outer medulla of mammalian kidney after selective removal of membrane components by sodium dodecylsulphate. Biochim Biophys Acta 356: 36-52, 1974.

KLIMEŠ I, ZICHA J, KUNEŠ J, ŠEBÕKOVÁ E: Hypertriglyceridemia, insulin resistance and hypertension in rats: are they related? Endocr Regul 31: 103-119, 1997.

LOWRY OH, ROSEBROUGH NJ, FARR AL, RANDALL RJ: Protein measurement with the folin phenol reagent. J Biol Chem 193: 265-275, 1951.

PALACIOS J, ESPINOZA F, MUNITA C, CIFUENTES F, MICHEA L: $\mathrm{Na}^{+}-\mathrm{K}^{+}-2 \mathrm{Cl}^{-}$cotransporter is implicated in gender differences in the response of the rat aorta to phenylephrine. Br J Pharmacol 148: 964-972, 2006.

QUINTAS LE, LOPEZ LB, SOUCCAR C, NOËL F: $\mathrm{Na}^{+} / \mathrm{K}^{+}$-ATPase density is sexually dimorphic in the adult rat kidney. Ann NY Acad Sci 834: 552-554, 1997.

SMITH JB, WADE MB, FINEBERG NS, WEINBERGER MH: Influence of race, sex, and blood pressure on erythrocyte sodium transport in humans. Hypertens 12: 251-258, 1988.

STUDER M, BRIEL M, LEIMENSTOLL B, GLASS TR, BUCHER HC: Effect of different antilipidemic agents and diets on mortality: a systematic review. Arch Intern Med 165: 725-730, 2005.

ŠIMKO F, LUPTÁK I, MATUŠKOVÁ J, BABÁL P, PECHÁŇOVÁ O, BERNÁTOVÁ I, HULÍN I: Heart remodeling in the hereditary hypertriglyceridemic (hHTG) rat: effect of captopril and nitric oxide deficiency. Ann NY Acad Sci 967: 454-462, 2002.

ŠIMKO F, PELOUCH V, TÖRÖK J, LUPTÁK I, MATUŠKOVÁ J, PECHÁŇOVÁ O, BABÁL P: Protein remodeling of the heart ventricles in hereditary hypertriglyceridemic rat: effect of ACE-inhibition. J Biomed Sci 12: 103$111,2005$.

TAUSSKY HH, SHORR EE: A microcolorimetric method for the determination of inorganic phosphorus. J Biol Chem 202: 675-685, 1953.

TAYLOR EA, GOH CR, OH VM: Influence of family history of cryptogenic hypertension, age, sex and race on lymphocyte sodium/potassium pump. Ann Acad Medicine Singapore 20: 308-313, 1991.

VLKOVIČOVÁ J, JAVORKOVÁ V, PECHÁŇOVÁ O, VRBJAR N: Gender difference in functional properties of $\mathrm{Na}, \mathrm{K}-\mathrm{ATPase}$ in the heart of spontaneously hypertensive rats. Life Sci 76: 971-982, 2005.

VRÁNA A, KAZDOVÁ L: The hereditary hypertriglyceridemic nonobese rat: an experimental model of human hypertriglyceridemia. Transpl Proc 22: 2579, 1990. 
ZICHA J, PECHÁŇOVÁ O, ČAČÁNYIOVÁ S, CEBOVÁ M, KRISTEK F, TÖRÖK J, ŠIMKO F, DOBEŠOVÁ Z, KUNEŠ J: Hereditary hypertriglyceridemic rat: A suitable model of cardiovascular disease and metabolic syndrome? Physiol Res 33: 49-63, 2006. 